\title{
Population shifts in two competing fish species on a degrading coral reef
}

\author{
Raymond D. Clarke* \\ Sarah Lawrence College, Biology Department, Bronxville, New York 10708-5999, USA
}

\begin{abstract}
I monitored the populations of 2 fishes on a coral reef in St. Croix, U. S. Virgin Islands, from 1980 to 1995 to determine if they could track changes in their habitat. Starting in the mid-1970s, white band disease killed all the elkhorn corals Acropora palmata, providing access to a variety of boring organisms that create the cavities inhabited by the spinyhead blenny Acanthemblemaria spinosa and the roughhead blenny $A$ aspera. As the corals became more heavily bored, they were weakened and collapsed, providing more of the low habitat occupied by roughheads and less of the high habitat occupied by spinyheads. This structural change was generally gradual but Hurricane Hugo destroyed almost all the remaining standing dead corals in 1989. Both species increased in density until 1989 when the sudden reduction of high habitat caused a decrease in spinyhead population density. In contrast, roughheads continued their population growth until 1991 after which they also declined. Although previous work has shown that spinyheads can displace roughheads from preferred habitat, spinyheads did not increase their numbers close to the reef surface as the high corals collapsed. I hypothesize that their inflexible minimum height is due to their previously demonstrated higher metabolic rate which constrains them to the higher locations where planktonic food is more abundant. Consequently, the species mix shifted from one of spinyheads with extremely rare roughheads in 1980 to one dominated by roughheads with few spinyheads in 1995 . This precise tracking of a changing environment suggests resource limitation and is counter to the widespread view that coral reef fish assemblages are largely unsaturated systems consisting of open, recruitment-linited populations. The fishes studied here may be atypical, however, and it is suggested that more studies with a mechanistic approach may provide insight into reef fish assemblage structure.
\end{abstract}

KEY WORDS: Recruitment limitation - Caribbean Competition - Microhabitat Storms Carrying capacity

\section{INTRODUCTION}

A key issue that has emerged from the attempts to understand the mechanisms determining the structure of coral reef fish assemblages is the degree to which the species are maintained at the carrying capacity. Their local populations appear to be largely open systems (Sale 1991). The planktonic larvae of many species disperse widely, so that factors affecting reproduction on a reef may have little effect on recruitment to that reef (Doherty \& Williams 1988). In this view, many species fail to fully utilize benthic resources due to limited recruitment from the larval stage, thus pre-

•E-mail: rclarke@mail.slc.edu cluding strong competitive effects on community structure (Doherty \& Williams 1988, Doherty 1991, Sale 1991, Doherty \& Fowler 1994j.

Warner \& Hughes (1988) have shown that most criteria used to differentiate between recruitment limitation and density-dependent effects (primarily competitionj in reef fishes are inadequate. The 'storage effect' can result in relatively stable adult densities below the carrying capacity even in the face of variable recruitment. Consequently, an unchanging population density is not indicative of post-recruitment density-dependent factors operating in a constant environment.

A different approach that avoids this problem is to determine whether fish populations can track changes in benthic resources. If they can do this, then we can conclude that recruitment is adequate to saturate 
the environment and that post-recruitment densitydependent competition keeps the populations near the changing carrying capacities. This study investigated changes in 2 fish species as their environment underwent a major alteration.

Of all coral reef fishes, the tube blenny family (Chaenopsidae), especially the genus Acanthemblemaria, is probably the most site-attached. These blennies spend virtually all their time residing in holes in dead coral with only their heads protruding. There is evidence that these holes limit fish density (Clarke 1989, Buchneim \& Hixon 1992). The blennies constantly scan the water and surrounding surfaces for small crustaceans, primarily copepods, which they capture by rapidly darting from their holes for a distance of 1 or 2 body lengths (Greenfield \& Greenfield 1982, Lindquist \& Kotrschal 1987, Clarke 1992).

The spinyhead blenny Acanthemblemaria spinosa and the roughnead bienny $A$. aspera arc the 2 most widespread species of Acanthemblemaria in the western Atlantic. They are found in the same habitat on Tague Bay Reef, St. Croix, U.S. Virgin Islands, where $96 \%$ of the individuals occur in dead elkhorn coral (author's unpubl. data). Both species prefer high locations in standing dead coral, where more planktonic food is available and where they experience higher growth rates and fecundity (Clarke 1989, 1992). Spinyheads have a higher metabolic rate and greater food requirements which may not be met close to the reef surface (Clarke 1992). Under experimental conditions, they displace roughheads to lower locations, and in nature, they are the sole occupants of the upper branches in the coral (Clarke 1989).

Tague Bay Reef is a bank-barrier reef on the northeast corner of St. Croix. Before the mid-1970s, it was dominated by elkhorn coral Acropora palmata, a tall branching species characteristic of shallow, windward reefs (Adey 1975). White band disease was first described from. Tague Bay Reef (Gladfelter 1982) and has had wide impact across the Caribbean region (Williams \& Bunkley-Williams 1990). The unidentified pathogen kills corals of the genus Acropora, including elkhorn coral. Upon its death, the coral is colonized by a variety of boring organisms which eventually die and leave cavities in a honeycombed, encrusted, dendriform structure (Warme 1977, Hutchings 1986, Moran \& Reaka 1988). Eventually the structure collapses and becomes rubble on the reef surface. In the initial description of the disease, Gladfelter (1982) predicted that the anticipated alteration in reef structure would cause a change in the composition of the fish assemblage living there.

Other factors have also altered Tague Bay Reef recently. Hurricanes David and Frederic affected the reef in 1979 (Rogers et al. 1982) and Hurricane Hugo knocked down some of the remaining standing dead elkhorn coral in 1989 (Hubbard et al. 1991). Between the hurricanes, there was an almost total die-off of the long-spined sea urchin Diadema antillarum (Lessios et al. 1984), which resulted in an increased standing crop of macroalgae on the dead coral surfaces (Carpenter 1988). The changes on Tague Bay Reef are very similar to those described by Hughes (1994) in Jamaica over the same time period with the exception that the bloom of macroalgae has been less pronounced because herbivorous fishes are not as depleted in St. Croix as in Jamaica.

This paper documents changes in spinyheads and roughheads on Tague Bay Reef over 15 yr Based on their microhabitat requirements before the structural collapse of the coral, I predicted that both species would increase as the amount of dead, bored coral increased. I further predicted that, as the coral collapsed, spinyheads would decrease while roughheads continued to increase. These predictions were confirmed, corroborating the hypothesis that local populations of these species track changes in microhabitat availability.

\section{METHODS}

The field site was a $500 \mathrm{~m}$ section of the western end of Tague Bay Reef, St. Croix. Hubbard et al. (1991) found that the destructive effects of Hurricane Hugo on that reef were spotty, with greater impact on the western portions. The section studied was indeed severely degraded by the storm (author's pers. obs.).

Reef structure was measured using chain transects (Rogers et al. 1994). The ratio of the distance along the reef surface to the straight line distance is the structural index, which is proportional to the height and degree of branching of the corals. Because elkhorn coral is tall, branched, and was the dominant coral on Tague Bay Reef, it is the major contributor to high values of the structural index. I carried out seven $10 \mathrm{~m}$ chain transects in 1995. These were selected at random by dropping a marker from the boat before entering the water After locating the marker underwater, I extended a tape measure $10 \mathrm{~m}$ in a pre-determined direction parallel to the axis of the reef. I placed the transects in the 3 to $10 \mathrm{~m}$ depth range to correspond with previous chain transects by other investigators. All earlier data are derived from other studies on the same section of reef on which the fish were censused.

I censused the fishes in December-January, 1979-80. and in July-August of 1986, 1988 through 1993, and 1995. The basic technique involved a series of five $1 \times$ $10 \mathrm{~m}$ belt transects situated anew each year with a roughly uniform dispersion over the same $500 \mathrm{~m}$ of reef 
at depths of 7 to $10 \mathrm{~m}$. The sites were not permanently marked and were selected haphazardly without reference to previous transect locations. In 1986 the transects were of different lengths and oriented in different ways (Clarke 1989). All roughheads and spinyheads in each square meter were recorded and their heights above the reef surface were measured to the nearest $10 \mathrm{~cm}$. Heights above the reef surface were not measured in 1988; instead, I recorded substrate types in each quadrat that year

The size of dead elkhorn coral colonies is on the scale of 1 to $2 \mathrm{~m}$. In view of this, one can ask whether fish numbers on adjacent $1 \mathrm{~m}^{2}$ quadrats in the belt transects are statistically independent of each other. I approached the question by determining the difference in fish counts between adjacent quadrats and comparing them with differences between nonadjacent quadrats. For each of the 30 belt transects between 1988 and 1993 I selected 2 adjacent pairs and 2 non-adjacent pairs. All selections were random without replacement; no quadrat was selected more than once. The results indicate no statistically significant difference between adjacent and random quadrats for either species (Table 1). The quadrats can therefore be treated as statistically independent samples

Because the quadrats were effectively independent and the fish distributions were clumped, the data were fitted to negative binomial distributions using Krebs' (1989) program, Negbinom. The $95 \%$ confidence limits for the mean densities were calculated based on the negative binomial distribution.

To establish that the spinyhead population drop was not due to causes other than loss of standing dead elkhorn coral, in 1993 I selected 15 colonies that were still largely intact (height range 80 to $110 \mathrm{~cm}$ ). I searched each colony for spinyheads and roughheads and measured the height above the reef surface of the location of each individual.

Table 1. Mean differences $( \pm 1 \mathrm{SE}$ ) in counts of spinyheads and roughheads between pairs of adjacent and non-adjacent quadrats randomly selected from the same transects. p-values are based on the Wilcoxon signed-ranks test; $\mathrm{n}=60$ for each mean

\begin{tabular}{|lccc|}
\hline Species & \multicolumn{2}{c}{ Quadrat pairing } & $p$ \\
& Adjacent & Non-adjacent & \\
\hline Spinyheads & $1.72 \pm 0.40$ & $1.72 \pm 0.32$ & 0.71 \\
Roughheads & $2.47 \pm 0.27$ & $2.79 \pm 0.36$ & 0.22 \\
\hline
\end{tabular}

\section{RESULTS}

In 1980 , the surface of Tague Bay Reef was composed primarily of standing colonies of elkhorn coral, more than $50 \%$ of them dead, and by 1992 the reef was largely pavement and rubble with occasional scattered corals (Fig. 1). The 1995 chain transects yielded a structural index of 1.7 and no living elkhorn coral although some small living colonies were seen on the reef. The structural index declined slowly from 1979 to 1988 after which a sharp drop coincided with the passage of Hurricane Hugo (Table 2). The overall reduction from 2.7 to 1.7 represents a large decline when one considers that a perfectly smooth surface gives a value of 1.0 .

The collapse of the elkhorn coral was clearly reflected in the changing vertical distributions of the blennies over the years (Fig. 2). Before Hurricane Hugo, $17 \%$ of spinyheads found in the belt transects were $>80 \mathrm{~cm}$ above the reef surface (1986 and 1989) whereas not one was found that high afterwards. The result was a drop in mean height above the reef surface from $58.6 \mathrm{~cm}$ in 1986 to $35.4 \mathrm{~cm}$ in $1991-93 \mathrm{com}-$ bined $\left(p<0.0001 ; \chi^{2}\right.$ test). Examination of 15 selected standing coral colonies in 1993 indicated that spinyheads were still distributed in high locations where available ('1993 Selected' in Fig. 2), with a greater average height than recorded from the transects in 1986 (69.8 vs $58.6 \mathrm{~cm}, \mathrm{p}<0.0001 ; \chi^{2}$ test). As the standing coral collapsed over time, there was no increase in spinyheads close to the reef surface (Fig. 2, Table 3). These data indicate an inflexibility with respect to height above the reef surface on the part of spinyheads. Roughheads exhibited no systematic change in mean heights (Fig 2) and were able to maintain their numbers close to the reef surface (Table 3 ).

The strong association of spinyheads with standing dead elkhorn coral was evident in 1993 when 45 of the 50 quadrats had no individuals and the remaining 5 had a total of 20 individuals, yet the average number on the 15 selected colonies was 13.0 and 2 supported 

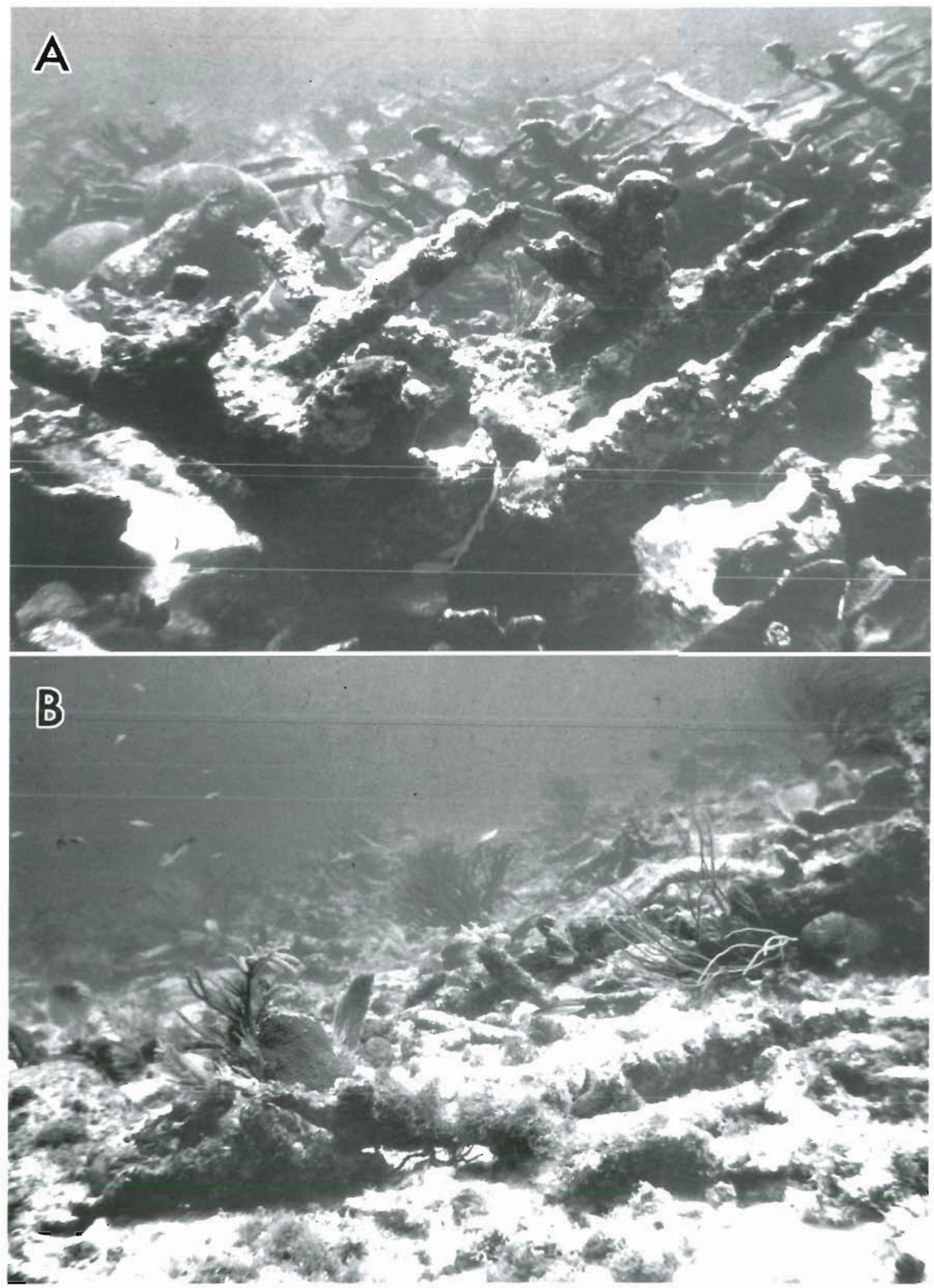

Fig. 1. (A) Typical view of Tague Bay Reef (St. Crolx, U.S. Virgin Islands) in 1980. The elkhorn coral in the foreground is dead but most colonies in the background are alive. (B) Representative view of Tague Bay Reef in 1992. Some areas were structurally much simpler than this, having been swept virtually clean of rubble by Hurricane Hugo. Note increased abundance of macroalgae in 1992 due to absence of long-spined sea urchins 


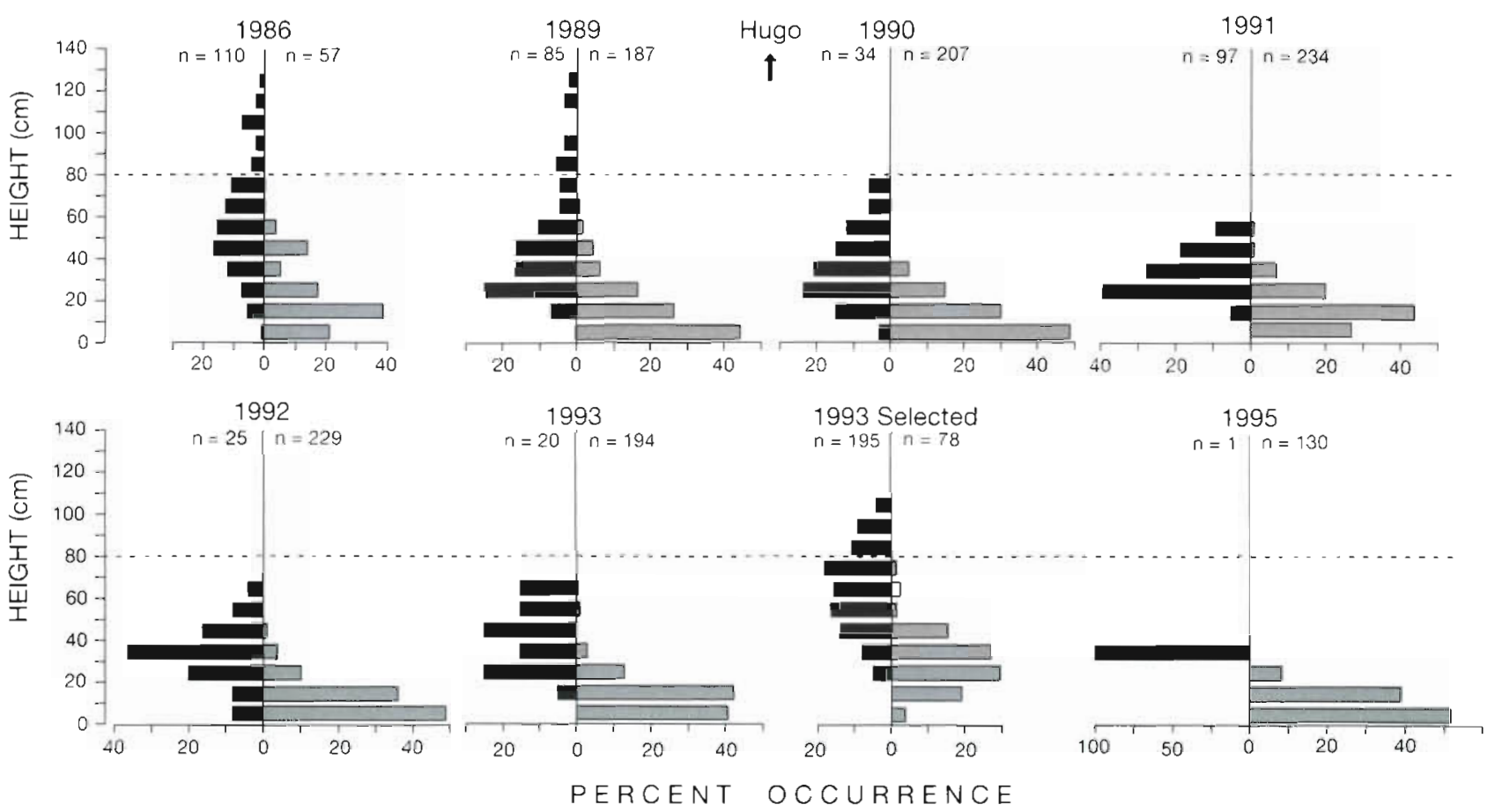

Fig. 2. Heights above the reef surface for blennies counted in belt transects. Spinyheads are on left (black bars) and roughheads are on right (gray bars). Dashed line is a reference indicating highest occurrence in 1990, the first census after Hurricane Hugo. The second data set for 1993 is derived from counts on 15 selected elkhorn coral colonies. Note that spinyhead bar for 1995 is based on 1 individual and is drawn to a different scale

23 and 27 , each more than in the entire $50 \mathrm{~m}^{2}$ surveyed in the transects. A colony studied in 1980, covering $<2 \mathrm{~m}^{2}$ of reef surface supported 58 spinyheads. This association is further demonstrated by the observation that spinyhead densities were closely dependent on substrate type whereas roughhead densities were considerably less substrate dependent (Table 4). Furthermore, Pearson correlation coefficients of number of fish per quadrat versus habitat type (habitat $=1$ or 2 for elkhorn coral and others respectively, see Malatesta et al. 1992) showed a strong positive relationship between spinyheads and dead elkhorn coral $\left(\mathrm{r}_{\mathrm{yx}}=0.56\right.$, $p<0.001$ ) whereas roughheads exhibited a weak negative relationship $\left(\mathrm{r}_{\mathrm{yx}}=-0.26, \mathrm{p}>0.05\right)$.

Table 3. Numbers of spinyheads and roughheads occurring in $50 \mathrm{~m}^{2}$ at heights $\leq 20 \mathrm{~cm}$ above the reef surface

\begin{tabular}{|ccc|}
\hline Year & Spinyheads & Roughheads \\
\hline 1986 & 7 & $41^{\mathrm{a}}$ \\
1989 & 6 & 132 \\
1990 & 6 & 164 \\
1991 & 5 & 170 \\
1992 & 4 & 195 \\
1993 & 1 & 161 \\
1005 & 0 & 119 \\
axtrapolated from $41 \mathrm{~m}^{2}$ & \\
\hline
\end{tabular}

Roughheads increased steadily from 1980 (0 in the belt transects and 3 as compared to $>4000$ spinyheads observed through various methods in 1979-80) until they peaked in 1991 and subsequently declined (Fig. 3). In contrast, spinyheads increased slightly until 1988 and then declined until only 1 was found in the belt transects in 1995. The switch in predominance halfway through the monitoring interval is statistically significant (non-overlapping confidence intervals in 1980 and post-1988 in Fig 3).

\section{DISCUSSION}

\section{Microhabitat changes and population sizes}

The general reef-wide collapse of dead elkhorn coral (Fig. 1, Table 2) is reflected in the height distributions of spinyheads, most prominently in the dropping out of higher values after Hurricane Hugo in 1989 (Fig. 2). The causal nature of this correlation is confirmed by the high values attained for spinyheads in the few remaining standing dead corals selected for study in 1993 (Fig. 2) which indicates a continuing preference for high locations by spinyheads.

I have previously shown that spinyheads have a higher metabolic rate, and consequent food require- 
Table 4. Mean densities of spinyheads and roughheads (fish $\mathrm{m}^{-2} \pm 1 \mathrm{SE}$ ) in 50 quadrats ciominated by 3 substrate types in 1988. Elkhorn coral refers to dead colonies either completely intact or tumbled over but largely intact. $n=$ number of quadrats dominated by each type of substrate

\begin{tabular}{|c|c|c|c|c|}
\hline \multirow{2}{*}{ Fish } & \multicolumn{3}{|c|}{ Predominant substrate } & \multirow{2}{*}{$\begin{array}{c}p \\
\text { (Kruskal- } \\
\text { Wallis test) }\end{array}$} \\
\hline & $\begin{array}{l}\text { High: } \\
\text { Elkhorn } \\
\text { coral }\end{array}$ & $\begin{array}{l}\text { Medium: } \\
\text { mixed } \\
\text { rubble }\end{array}$ & $\begin{array}{l}\text { Low: } \\
\text { sand or } \\
\text { pavement }\end{array}$ & \\
\hline Spinyheads & $6.86 \pm 1.59$ & $0.70 \pm 0.22$ & 0 & $<0.0001$ \\
\hline Roughheads & $2.57 \pm 0.39$ & $3.96 \pm 0.40$ & $217 \pm 0.65$ & $<0.02$ \\
\hline $\mathrm{n}$ & 21 & 23 & 6 & - \\
\hline
\end{tabular}

(Fig. 2, Table 3). Roughheads increased only after the coral began to collapse and provide shelters in rubble where spinyheads could not persist.

I expect that as the elkhorn coral rubble is further eroded into finer material the roughheads will continue to decrease in density on Tague Bay Reef. If the elkhorn coral does not recover, the reef will eventually support a low population of roughheads and virtually no spinyheads, the opposite of the condition before the coral was ment, than roughheads and that this makes the low sites on the reef unavailable to spinyheads because they receive insufficient planktonic food close to the reef surface (Clarke 1989, 1992). There is no upper limit to high sites other than the water surface; I have seen spinyheads $10 \mathrm{~m}$ above lile seafloor on pilings supporting the pier at Frederiksted, St. Croix. In nature, the dead coral sets the upper limit and this was lowered on Tague Bay Reef from 1980 to 1995, thus reducing available habitat because spinyheads have a rigid lower limit.

As the dead elkhorn coral collapsed, rubble accumulated on the reef surface providing increased habitat for roughheads which have no lower height limit on Tague Bay Reef (Clarke 1989, 1992) The density patterns shown in Fig. 3 are therefore consistent with the known biology of these species. Spinyheads increased first because they apparently out-competed roughheads in the standing elkhorn coral which both species prefer. As the coral collapsed, they were squeezed between the descending upper limit of the coral and their inflexible lower limit defined by food availability

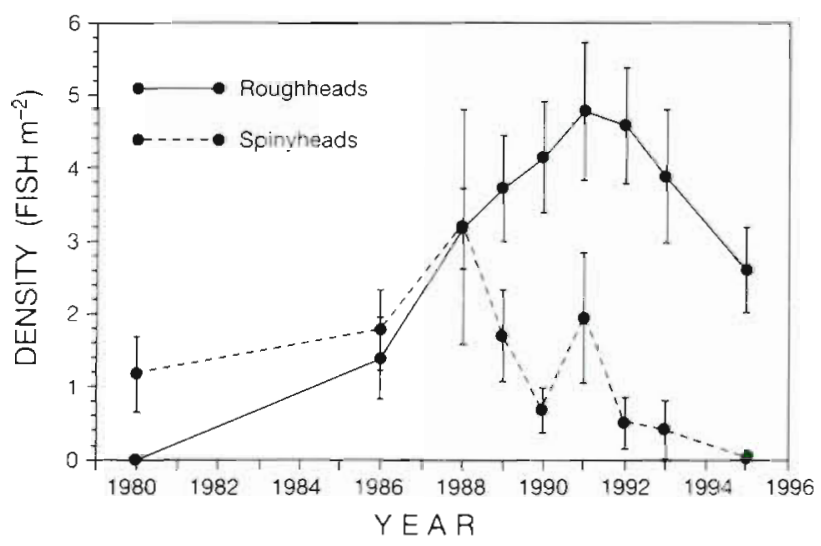

Fig. 3. Mean densities of spinyhead and roughhead blennies on Tague Bay Reef from 1980 to 1995. Error bars represent $95 \%$ confidence limits for the means as calculated for the negative binomial distribution. Taller error bar for 1988 is for spinyheads, $\mathrm{n} \equiv 50$ in all years but 1986 when $\mathrm{n}=51$ and 41 for spinyheads and roughheads, respectively destroyed. This temporal shift is analogous to observed spatial changes elsewhere; on the Belizean barrier reef both spinyheads and roughheads are abundant in the high spur and groove zone but only roughheads are present in the low spur and groove zone (Clarke 1994).

\section{Significance to assemblage structure}

The conclusions presented here indicate that environmental tracking and precise microhabitat utilization can occur in tube blennies. Nevertheless, this may not be the general case for reef fishes. Because chaenopsid blennies live in close-fitting blind tubes, they probably experience very low predation rates. In aquaria these species can live for 4 yr (author's pers. obs.) so that with little loss to predators, individuals may persist for some time in the populations. If turnover is therefore low, then a low rate of recruitment may allow the populations to saturate the environment. This would contrast with many other reef fishes which experience high mortality due to predators, especially as small juveniles in the size range of adult spinyheads and roughheads (Shulman \& Ogden 1987, review by Hixon 1991). For these fishes, a much higher recruitment would be necessary to saturate the environment and these species may indeed be recruitment-limited (Victor 1986)

Several studies have demonstrated that habitat structure affects the occurrences and relative abundances of fish species on coral reefs (Smith \& Tyler 1975, Gladfelter et al. 1980, Kaufman \& Ebersole 1984, Alevizon et al, 1985, Sano et al. 1987, Hixon \& Beets 1993). Whereas those studies monitored whole assemblages, this study concentrates on only 2 species and consequently allows an understanding of distributions starting from the basic autecology of each species. This mechanistic approach can eventually provide a basis for detailed understanding of community dynamics by promoting models based on fundamental biology rather than higher level mathematical constructs incorporating simplifying assumptions ('megaparameters'; 
Schoener 1986). Moermond (1986) has demonstrated the value of this approach in studies of Anolis sp. lizards. One consequence of such an approach would be a greater appreciation of the potential for different dynamics of different species and the need to incorporate these differences into community models.

Such an approach may prove useful in ascertaining the extent to which post-settlement deterministic processes govern species abundances. Sale et al. (1994) indicated that they generally do not, but this is difficult to demonstrate conclusively without detailed studies of each species. On the other hand, small hole-dwelling fishes such as those studied here may be much more responsive to microhabitat features than most reef fishes (Greenfield \& Johnson 1990, Clarke 1994), and therefore not representative of the assemblage. Clearly, no single taxonomic group can serve as a suitable model for the dynamics of coral reef fishes. Perhaps detailed study of a few species over a wide geographic area, selected for diverse life histories and ecological requirements, would help determine the extent to which predation and competition determine the occurrences and relative abundances of fish species on coral reefs.

Acknowledgements. I thank Karen Clarke for assisting in the field throughout the project and the colleagues who supplied logistical support over the years: John Bythell, Bob Dill, Betsy Gladfelter, Denny Hubbard, John Ogden, Chris Petersen, Bob Warner, Jordan West and David Yocum. Bob Steneck and Karla Parsons kindly shared their chain transect data with me. Mark Hixon, Bob Warner, and 2 anonymous reviewers provided very helpful comments on the manuscript. Parts of this study were supported by The American Philosophical Society and a Flik Travel Grant for Fieldwork.

\section{LITERATURE CITED}

Adey WH (1975) The algal ridges and coral reefs of St. Croix: their structure and Holocene development. Atoll Res Bull 187

Alevizon W, Richardson R, Pitts P, Serviss G (1985) Coral zonation and patterns of community structure in Bahamian reef fishes. Bull Mar Sci 36:304-318

Buchheim JR, Hixon MA (1992) Competition for shelter holes in the coral-reef fish Acanthemblemaria spinosa Metzelaar. J Exp Mar Biol Ecol 164:45-54

Carpenter RC (1988) Mass mortality of a Caribbean sea urchin: immediate effects on community metabolism and other herbivores. Proc Natl Acad Sci, USA 85:511-514

Clarke RD (1989) Population fluctuation, competition and microhabitat distribution of two species of tube blennies, Acanthemblemaria (Teleostei: Chaenopsidae). Bull Mar Sci 44:1174-1185

Clarke RD (1992) Effects of microhabitat and metabolic rate on food intake, arowth and fecundity of two rompeting coral reef fishes. Coral Reefs 11:199-205

Clarke RD (1994) Habitat partitioning by chaenopsid blennies in Belize and the Virgin Islands. Copeia 1994:398-405
Doherty PJ (1991) Spatial and temporal patterns in recruitment. In: Sale PF (ed) The ecology of fishes on coral reefs. Academic Press, San Diego, p 261-293

Doherty PJ, Fowler T (1994) An empirical test of recruitment limitation in a coral reef fish. Science 263:935-939

Doherty PJ, Williams DMcB (1988) The replenishment of coral reef fish populations. Oceanogr Mar Biol A Rev 26: $487-551$

Gladfelter WB (1982) White-band disease in Acropora palmata: implications for the structure and growth of shallow reefs. Bull Mar Sci 32:639-643

Gladfelter WB, Ogden JC, Gladfelter EH (1980) Similarity and diversity among coral reef fish communities: a comparison between tropical western Atlantic (Virgin Islands) and tropical central Pacific (Marshall Islands) patch reefs. Ecology 61:1156-1168

Greenfield DW, Greenfield TA (1982) Habitat and resource partitioning between two species of Acanthemblemaria (Pisces: Chaenopsidae), with comments on the chaos hypothesis. Smithson Contr Mar Sci 12:499-507

Greenfield DW, Johnson RK (1990) Community structure of western Caribbean blennioid fishes. Copeia 1990:433-448

Hixon MA (1991) Predation as a process structuring coral reef fish communities. In: Sale PF (ed) The ecology of fishes on coral reefs. Academic Press, San Diego, p 475-508

Hixon MA, Beets JP (1993) Predation, prey refuges, and the structure of coral-reef fish assemblages. Ecol Monogr 63:77-101

Hubbard DK, Parsons KM, Bythell JC, Walker ND (1991) The effects of Hurncane Hugo on the reefs and associated environments of St. Croix, U.S. Virgin Islands-a preliminary assessment. J Coastal Res Spec Issue 8:33-48

Hughes TP (1994) Cutastrophes, phase shifts, and large-scale degradation of a Caribbean coral reef. Science 265: $1547-1551$

Hutchings PA (1986) Biological destruction of coral reefs. Coral Reefs 4:239-252

Kaufman LS, Ebersole JP (1984) Microtopography and the organization of two assemblages of coral reef fishes in the West Indies. J Exp Mar Biol Ecol 78:253-268

Krebs CJ (1989) Ecological methodology. Harper \& Row, New York

Lessios HA, Robertson DR, Cubit JD (1984) Spread of Diadema mass mortality through the Caribbean. Science 226:335-337.

Lindquist DG, Kotrschal KM (1987) The diets in four Pacific tube blennies (Acanthemblemaria: Chaenopsidae): lack of ecological divergence in syntopic species. Mar Ecol 8: $327-335$

Malatesta RJ, Auster PJ, Carlin BP (1992) Analysis of transect data for microhabitat correlations and faunal patchiness. Mar Ecol Prog Ser 87:189-195

Moermond TC (1986) A mechanistic approach to the structure of animal communities: Anolis lizards and birds. Am Zool $26: 23-37$

Moran DP, Reaka ML (1988) Bioerosion and availability of shelter for benthic reef organisms. Mar Ecol Prog Ser $44: 249-263$

Rogers CS, Garrison G, Grober R, Hillis ZM, Franke MA (1994) Coral reef monitoring manual for the Caribbean and western Atlantic. Virgin Islands National Park, U.S. National Park Service

Rogers CS, Suchanek TH, Pecora FA (1982) Effects of Hurricanes Darid and Froderic (1973) un sildiluw Acropora palmata reef communities: St. Croix, U.S. Virgin Islands. Bull Mar Sci 32:532-548

Sale PF (1991) Reef fish communities: open nonequilibrial 
systems. In: Sale PF (ed) The ecology of fishes on coral reefs. Academic Press, San Diego, p 564-598

Sale PF, Guy JA, Steel WJ (1994) Ecological structure of assemblages of coral reef fishes on isolated patch reefs. Oecologia 98:83-99

Sano M. Shimizu M. Nose Y (1987) Long-term effects of destruction of hermatypic corals by Acanthaster planci infestation on reef fish communities at Iriomote Island Japan. Mar Ecol Prog Ser 37:191-199

Schoener TW (1986) Mechanistic approaches to community ecology: a new reductionism? Am Zool 26:81-106

Shulman MJ, Ogden JC (1987) What controls tropical reef fish populations: recruitment or benthic mortality? An example in the Caribbean reef fish Haemulon flavolineatum. Mar Ecol Prog Ser 39:233-242

This article was presented by C. H. Peterson (Senior Editorial Advisor), Morehead City, North Carolina, USA
Smith CL, Tyler JC (1975) Succession and stability in fish communities of dome-shaped patch reefs in the West Indies. Am Mus Novit 2572

Victor BC (1986) Larval settlement and juvenile mortality in a recruitment-limited coral reef fish population. Ecol Monogr 56:145-160

Warme JE (1977) Carbonate borers - their role in reef ecology and preservation. Am Ass Petroleum Geol, Stud Geol $4: 261-279$

Warner RR, Hughes TP (1988) The population dynamics of reef fishes. Proc 6th Int Symp Coral Reefs 1: $149-155$

Williams EHJ, Bunkley-Williams L (1990) The world-wide coral reef bleaching cycle and related sources of coral mortality. Atoll Res Bull 335

Manuscript first received: September 7, 1995

Revised version accepted: Frbruary 21, 1996 